\title{
PERTIMBANGAN HAKIM DALAM MEMUTUSKAN TINDAK PIDANA PEMBOBOLAN BANK MELALUI ATM
}

\author{
Ida Ayu Gede Kristina Dewi, I Nyoman Gede Sugiartha, Ida Ayu Putu Widiati \\ Fakultas Hukum Universitas Warmadewa, Denpasar - Bali, Indonesia
}

\begin{abstract}
Abstrak
Dewasa ini, dengan kemajuan teknologi dan informasi maka tindak pidana juga sering terjadi, Anjungan Tunai Mandiri (ATM) di dunia perbankan adalah bentukLayanan Nasabah Bank dengan menggunakan mesin atau bisa dikatakan perangkat elektronik. Karena kecanggihan teknologi ini sepertiyang kita ketahui kejahatan cyber adalah bentuk baru dari kejahatan kontemporer yang telah disorot luas di seluruh dunia. Pengguna ATM disini menjadi korban karena adanya kejahatan melalui sistem elektronik ini dengan memanfaatkan dan melihat virtualnya. Penelitian ini bertujuan untuk mengetahui pengaturan sanksi pidana dan pertimbangan hakim dalam memutuskan tindak pidana pembobolan bank melalui ATM. Metode yang di gunakan pada penelitian ini adalah metode normatif. Berdasarkan penelitian didapati bahwa peraturan sanksi pidana terhadap tindak pidana perampokan account melalui Anjungan Tunai Mandiri (ATM) dalam hukum KUHP yang terkandung dalam Pasal 362 KUHP, dalam UU ITE pencurian tersebut terkandung dalam Pasal 30 ayat (1), Pasal 30 ayat (3), Pasal 32 ayat (2), Pasal 32 ayat (3), Pasal 36. Dan ada penambahan dari UU Nomor 3 dari 2011 mengenai transfer dana pencurian yang terkandung dalam Pasal 81, Pasal 83 ayat (1), Pasal 83 ayat (2), nomor keputusan:688/PID. B/2012/PN. Hakim memutuskan kasus bahwa terdakwa teguh $\mathrm{T}$ khasan telah terbukti secara legal dan meyakinkan bersalah melakukan kejahatan terhadap hukum membeli, menyewakan, bertukar, menerima sebagai janji, menerima sebagai hadiah atau dengan harapan mendapatkan keuntungan menjual, menyimpan, bertukar, menggadaikan, diangkut, disimpan atau disembunyikan item.
\end{abstract}

Kata Kunci: Anjungan Tunai Mandiri (ATM); Pembobolan; Tindak Pidana

\begin{abstract}
Nowadays, with advances in technology and information, criminal acts also often occur, Automated Teller Machines (ATM) in the banking world is a form of Bank Customer Service using machines or can be said to be electronic devices. Because of this technological sophistication as we know cybercrime is a new form of contemporary crime that has been highlighted widely throughout the world. ATM users here become victims because of crime through this electronic system by utilizing and seeing their virtual. This study aims to determine the regulation of criminal sanctions and judge considerations in deciding criminal acts of bank burglary through ATMs. The method used in this study is a normative method. Based on the research, it was found that the regulation of criminal sanctions against account robbery through the Automatic Teller Machine (ATM) in the Criminal Code law contained in Article 362 of the Criminal Code, in the ITE Law the theft is contained in Article 30 paragraph (1), Article 30 paragraph (3), Article 32 paragraph (2), Article 32 paragraph (3), Article 36. And there are additions to Law Number 3 of 2011 concerning the transfer of theft funds contained in Article 81, Article 83 paragraph (1), Article 83 paragraph (2), Decision number: 688/PID. B/2012/PN. The judge ruled the case that the defendant was firmly proven legally and convincingly guilty of committing a crime against the law of buying, renting, exchanging, accepting as a promise, accepting as a gift or in the hope of profiting, selling, storing, exchanging, mortgaging, transporting, storing or hiding the item.
\end{abstract}

Keywords: ATM robbery crime; judge's consideration; technology and information

\section{PENDAHULUAN}

Indonesia merupakan negara-negara hukum dimana setiap tindakan dan perilaku masyarakatnya diatur dalam aturan yang di buat pemerintah demi mengurangi tingkat kejahatan. Berbagai macam kejahatan sering terjadi di Indonesia mulai dari pencurian, pemerkosaan, penipuan sampai pembunuhan. Kasus yang paling sering terjadi di Indonesia ialah pencurian, banyak modus digunakan pelaku untuk 
melancarkan aksinya mulai dari mencuri barang di rumah target sampai membobol ATM. Secara khusus penelitian ini akan membahas tindak pidana pencurian yang dilakukan dengan cara membobol ATM. Kejahatan tersebut sering dilakukan pada malam hari saat warga sekitar sedang tidur dan tindakan tersebut sangat jarang diketahui orang banyak sampai akhirnya pelaku tertangkap oleh pihak yang berwajib.

Pada Pasal 363 KUHP ayat (2) menjelaskan bahwa apabila terjadi pencurian akan dikenakan pidana penjara paling lama 9 (sembilan) tahun dilihat dari ayat 4 dan 5 Pasal 363 ayat 1 pada KUHP. Pada Pasal 364 (KUHP) menjelaskan bahwa segala perbuatan yang dilakukan dalam Pasal pencurian didalam KUHP, akan dijatuhkan pidana penjara paling lama 3 (tiga) bulan atau denda pidana paling banyak dua ratus lima puluh rupiah apabila pencurian tidak dilakukan dalam rumah dan harga barang yang dicuri tidak lebih dari dua puluh lima rupiah. Sedangkan pada Pasal365 KUHP ayat 1 menjelaskan mengenai pengancaman atas pidana paling lama 9 (sembilan) tahun, pencurian yang sudah dilakukan disertai kekerasan atau mengancam kekerasan terhadapkorban dengan keinginan untuk mempersiapkan ataumempermudah pencurian itu, dan apabila tertangkap tangan, untuk memungkinkan diri sendiri atau peserta lainnya untuk melarikan diri, atau untuk tetap menguasai barang yang dicuri.

Dalam Pasal 365 Kitab Undang - Undang Hukum Pidana (KUHP) ayat 2 menyatakan bahwa diancam dengan pidana penjara paling lama duabelas tahun bila perbuatan dilakukan pada waktu malam dalam sebuah rumah atau di pekarangan tertutup yang ada rumahnya, di jalan umum, atau dalam kereta api atau trem yang sedang berjalan, bila perbuatan dilakukan oleh dua orang atau lebih dengan bersekutu, bila yang bersalah masuk ke tempat melakukan kejahatan dengan merusak atau memanjat, atau dengan memakai anak kunci palsu, perintah palsu atau pakaian jabatan palsu, dan bila perbuatan mengakibatkan luka berat.

Dalam Pasal 365 Kitab Undang - Undang Hukum Pidana (KUHP) ayat 3 menyatakan bahwa: "Bila perbuatan itu mengakibatkan kematian, maka yang bersalah diancam dengan pidana penjara paling lama lima belas tahun.” Dalam Pasal 365 Kitab Undang - Undang Hukum Pidana (KUHP) ayat 4 menyatakan bahwa diancam dengan pidana mati atau pidana penjara seumur hidup atau selama waktu tertentu paling lama dua puluh tahun, jika perbuatan mengakibatkan luka berat atau kematian dan dilakukan oleh dua orang atau lebih dengan bersekutu, disertai pula oleh salah satu hal yang diterangkan dalam pasal 365 ayat 1 dan ayat 3 (Sudarsono, 1992).

Berdasarkan pertimbangan majelis hakim uraian tersebut mengenai arti tindak pidana menurut pandangan Hukum pidananya yang ada dalam kejahatan tersebut memiliki unsur atau tindak pidananya seperti pencurian dan pemalsuan data yang lebih sering disebut dengan keterangan palsu atas tindakan pidana yang terdapat dalam KUHP adalah kejahatan dengan cara baru, sehingga membutuhkkan waktu untuk mengamatin dan cermati dalam tindakan pidana tersebut agar dapat ditentukan perubahan apa saja yang terjadi dalam tindakan kriminal tersebut sesuai dengan kecanggihan zaman sekarang, jadi hukuman atau delik bagi pelaku tindak pidana pembobolan rekening melalui ATM dalam studi Putusan Nomor 688/Pid.B/2012/PN.Dps.

Beberapa penelitian serupa juga dilakukan, diantaranya tentang penerapan sanksi terhadaptindak pidana pencurian dengan cara pembobolan anjungan tunai mandiri (studi kasus di BCA Denpasar) mengungkapkan bahwa pada kasus pencurian ATM bank yang terjadi saat ini, pelaku pencurian rekening nasabah bank bisa dijerat dengan pasal-pasal dalam UU No. 11-2008. Hakim menjatuhkan sanksi pidana penjara 8 (delapan) bulan dan denda sebesar Rp 60.000.000,- dengan ketentuan apabila denda tersebut tidak dibayar, diganti pidana penjara 2 (dua) bulan (Siregar \& Swardhana, 2016). Penelitian lain tentang penanggulangan tindak pidana pembobolan Anjungan Tunai Mandiri oleh Polri mengemukakan bahwa tindakan terkait dengan penanggulangan tindak pidana pembobolan ATM. Rangkaian tindakan ini bersifat preventif dan represif (Wardhana, 2011). Dan Penerapan sanksi yang dijatuhkan majelis hakim pada putusan No.403/Pid.B/2011/PN.Mks dengan menjatuhkan sanksi minimal tanpa lebih mempertimbangkan alasan yang dapat memperberat hukuman terdakwa (Amalia, 2015).

Dari latar belakang yang telah diuraikan tersebut, maka terdapat 2 (dua) rumusan masalah yang akan di bahas pada penelitian ini, yaitu bagaimanakah pengaturan sanksi pidana terhadap tindak pidana pembobolan bank melalui ATM? Dan bagaimanakah pertimbangan Hakim dalam memutuskan tindak pidana pembobolan bank melalui ATM? Dari rumusan masalah tersebut, tujuan penelitian ini adalah untuk mengetahui pengaturan sanksi pidana dan pertimbangan hakim dalam memutuskan tindak pidana pembobolan bank melalui ATM. 


\section{METODE PENELITIAN}

Metode yang digunakan dalam penelitian ini ialah metode metode normatif dimana dalam pengerjaannya penulis menlaah isu hukum dengan didasari peraturan - peraturan hukum Perbankan di Indonesia (Ahmad, 2008). Jenis data pada penelitian ini ialah data primer, sekunder, dan tersier. Data yang didapatkan bersumber dari kepustakaan yang berdasarkan hukum dalam bentuk literatur ataupun peraturan yang berlaku di masyarakat (Waluyo, 2002). Pendekatan perundangan-undangan adalah pendekatan pada suatu penelitian yang dilakukan dengan berpatokan pada undang - undang sebagai acuan. Pendekatan kasus dilakukan guna melihat, mencatat dan memahami permasalahan yang diangkat dalam penelitian dengan tidak keluar dari zona hukum positif. Teknik pengumpulan sumber hukum digunakan dalam penelitian ini berupa rekaman serta dokumentasi.

\section{HASIL DAN PEMBAHASAN}

Rekening merupakan alat transaksi yang setiap penggunanya dapat menyimpan uang demi menghindari kejahatan pencurian atau perampokan yang marak terjadi saat ini. Demi dapat memiliki rekening seseorang harus mengisi formulir pendaftaran terlebih dahulu, memiliki minimal seratus ribu saldo mengendap dalam rekening agar rekening tidak hangus saat tidak terjadi transaksi antara pihak bank dengan nasabah semisal tidak menabung selama beberapa bulan.

Adanya perkembangan zaman yang semakin canggih maka muncullah faktor terpenting untuk menarik daya pikat nasabah dalam dunia perbankan yakni dengan mencetuskan sebuah pelayanan untuk nasabah bank dari instansi yakni bank sendiri dengan memberikan kemudahan untuk menarik uang dimana saja tanpa harus mengantri dan mengisi formulir yang nantinya akan di serahkan kepada teller, hal dimaksudkan dalam penjelasan diatas ialah dunia bank memberikan pelayanan dalam sebuah mesin yang dijalankan oleh elektronik untuk nasabah bank dalam pelayanan bank konvensional yakni dinamakan sebagai mesin ATM. Biasanya nasabah tertarik dengan kemudahan yang ditawarkan karena dianggap lebih efisien dan simple. Selain pelayanan yang diberikan oleh bank tidak saja hanya pelayanan teller dan costumer sevice tetapi juga penawaran produk yang sering dilakukan oleh nasabah seperti transfer bayar cicilan, dll, hal ini cukup hanya dengan menggunakan ATM yang dikenal istilah di Indonesia ialah Anjungan Tunai Mandiri.

Bentuknya berupa alat elektronik atau mesin yang dijalankan oleh sistem elektronik yang bertugas menggantikan manusia (kasir), dengan fasilitas bahwa nasabah bank dapat melakukan layanan untuk menarik uang dan memeriksa saldo ATMnya. Sehingga, dengan mesin elektronik itu transaksi dapat berjalan efektif tanpa perlu menambah tenaga manusia.

ATM ialah sebuah alat elektronik yang berbentuk mesin yang memiliki fasilitas layanan seperti pada kantor bank hanya saja yang membedakan adalah tidak ada seorang teller bank. ATM ini dirasa oleh masyarakat sangatlah memudahkan mereka dalam melakukan transaksi di era modern ini, akan tetapi walaupun mudah tetapi ATM ini tetap dalam pengawasan oleh peraturan dalam dunia perbankan. Dapat diartikan bahwa anjungan tunai mandiri (ATM) sangatlah memudahkan seseorang untuk melakukan transaksi di zaman moderen ini, tetapi penggunaan anjungan tunai mandiri (ATM) tidak terlepas dari aturan Hukum Perbankan, aturan hukum perbankan Langkah pertama-tama kita harus mengamati dan mengetahui Dasar Hukum yang mengatur tentang perbankan sesuai dengan Undang Undang.

Dari penjelasan di atas dapat kita pahami Anjungan Tunai Mandiri atau disingkat dengan sebutan (ATM) bentuknya berupa alat elektronik yang bertugas untuk menggantikan manusia, dengan mengatur nasabah bank untuk mengambil sejumlah uang, mentransfer uang dari bank yang satu ke bank lainnya, mengecek saldo rekening tabungan, melakukan setoran tunai dan masih banyak fungsi-fungsi yang lainnya. Kendati rekening seperti yang telah disebutkan di atas digunakan untuk menghindari pencurian, tetap saja di dalam kemudahan akses ini menyebabkan besar kemungkinan untuk terjadinya kejahatan di dunia Perbankan karena mesin Anjungan Tunai Mandiri (ATM) tersebar di seluruh tempat umum di berbagai daerah dan termasuk fasilitas publik. Undang-Undang Nomor 10 tahun 1998 tentang perbankan dapat dikatakan bahwa tidak memuat secara terperinci ketentuan mengenai perlindungan hukum bagi Nasabah Bank. Kendati demikian, upaya yang dapat ditempuh dalam memberikan perlindungan bagi nasabah yang mengalami kerugian karena pembobolan, yaitu secara non litigasi dan secara litigasi (Utami \& Taufiq, 2018). Dalam dunia perbankan, pada jaman yang serba canggih dan praktis ini, seperti yang telah kita ketahui banyak sekali motif-motif kejahatan baru, seiring 
berkembangnya jaman maka tindak kejahatanpun semakin berkembang, salah satunya adalah tindak kejahatan yang dikenal dengan istilah Skiming.

Kejahatan perbankan melalui metode skimming masih kerap terjadi (Ekawati, 2018). Pembobolan ATM menggunakan teknik Skimming merupakan modus operandi canggih dalam pembobolan bank yang melanggar beberapa aturan pidana dalam UU ITE dan KUHP (Enrick, 2019). Sebagai pemegang rekening atau kartu Anjungan Tunai Mandiri (ATM) harus berhati-hati. Karena skimmer memiliki cara-carayang canggih untuk membobol Anjungan Tunai Mandiri (ATM). Biasanya mereka cukup dengan komputer/laptop, software decoder hingga encoder kartu khusus. Kartu magnetik kosong dan pembacanya.

Dalam pembahasan di atas dalam hal kejahatan pembobolan Rekening Anjungan Tunai Mandiri (ATM) dapat dikualisifikasikan sebagai Tindak Pidana Pencurian menurut Pasal 362 KUHP, Dan dikualisifikasikan juga dalam Undang- Undang Nomor 11 Tahun 2008 Tentang Informasi Dan Transaksi Elektronik pada Pasal 30 ayat 1 dan 3, dan Pasal36 Undang-Undang Nomor 11 Tahun 2008

Tentang Informasi Dan Transaksi Elektronik, dan Pasal 81 Undang-Undang Nomor 3 Tahun 2011 Tentang Transfer Dana, Serta Pasal 83 Ayat 2 Undang-Undang Nomor 3 Tahun 2011 Tentang Transfer Dana. Berbicara dalam hal sanksi hukum terhadap pelaku tindak pidana pembobolan rekening anjungan tunai mandiri (ATM), pelaku pastinya akan dikenakan sanksi pidana. tindak pidana pembobolan rekening anjungan tunai mandiri (ATM) dapat dikategorikan juga sebagai pencurian dan termasuk kejahatan ITE yang diatur Dalam Pasal 365 Kitab Undang- Undang Hukum Pidana (KUHP). Sayangnya UU ITE masih memiliki batasan khusus karena dimensi perlindungan konsumennya (Samudra, 2019). Pasal 52 ayat (3) Undang - Undang Nomor 11 Tahun 2008 di tujukan apabila kejahatan tersebut dilakukan terhadap Komputer dan/atau Sistem Elektronik serta Informasi Elektronik dan/atau Dokumen Elektronik milik Pemerintah dan/atau badan strategis termasuk dan tidak terbatas pada lembaga pertahanan, bank sentral, perbankan, keuangan, lembaga internasional, otoritas penerbangan diancam dengan pidana maksimal ancaman pidana pokok masing-masing Pasal ditambah dua pertiga. Apabila menurut Pasal 86 Undang-Undang Nomor 3 Tahun 2011 tentang Transfer Dana apabila dilakukan oleh pengurus, pejabat, dan/atau pegawai Penyelenggara, dipidana dengan pidana pokok maksimum ditambah 1/3 (satu pertiga). Tetapi fonis hukuman yang akan di jatuhkan oleh hakim tentunya tetap menggunakan berbagai pertimbangan pertimbangan dalam menjatuhkan putusan dan tidak semata-mata hanya berpatokan dalam ketentuan Undang-Undang yang di sebutkan di atas.

Hukum indonesia sudah tidak asing lagi mengenai kata delik, Kata "delik" berasal dari bahasa Latin, yakni delictum. Dalam bahasa Jerman disebut delict, dalam bahasa Prancis disebut delit, dan dalam bahasa Belanda disebut delict. Dalam Kamus Besar Bahasa Indonesia, arti delik diberi batasan sebagai berikut. "Perbuatan yang dapat dikenakan hukuman karena merupakan pelanggaran terhadap undang-undang; tindak pidana". Hukum pidana memakai istilah peristiwa pidana karena istilah peristiwa itu meliputi suatu perbuatan (handelen atau doen) atau suatu melalaikan (verzuin atau nalaten) maupun akibatnya (keadaan yang ditimbulkan oleh karena perbuatan atau melalaikan itu), dan peristiwa pidana adalah suatu peristiwa hukum, yaitu suatu peristiwa kemasyarakatan yang membawa akibat yang diatur oleh hukum (Utrecht, 1963).

Dalam ilmu hukum pidana dikenal delik materiil dan delik formil. Adapun delik materiil adalah delik yang perumusannya menitik beratkan pada akibat yang dilarang dan diancam dengan pidana oleh undang-undang. Dengan kata lain, hanya disebut rumusan dari akibat perbuatan. Misalnya Pasal 338 tentang pembunuhan. Sedangkan yang dimaksud dengan delik formil adalah delik yang perumusannya menitik beratkan pada perbuatan yang dilarang dan diancam dengan pidana oleh undang-undang, dalam artian rumusan dari perbuatan itu jelas. Misalnya Pasal362 tentang pencurian (Prodjodikoro, 2003).

Delik Tindak Pidana Pembobolan Rekening Melalui Anjungan Tunai Mandiri (ATM) ini termasuk dalam tindak pidana pencurian karena pembobolan termasuk mengambil hak orang lain yang seharusnya tidak milik si pembobol Rekening Anjungan Tunai Mandiri (ATM). Pada dasarnya setiap perbuatan yang mengandung unsur-unsur kejahatan baik itu mengambil atau merampas hak orang lain yang di anggap sebagai suatu tindakan melanggar hukum/kejahatan baik di sengaja maupun tidak di sengaja diancam dengan pidana oleh undang-undang masing-masing memiliki sanksi ancaman pidana yang tindakannya tersebut harus dipertanggungjawabkan dan telah dinyatakan sebagai suatu tindakan yang merupakan suatu tindak kejahatan tentunya dapat di hukum sesuai undang- undang yang berlaku (Prasetyo, 2010). 
Dalam hal ini dapat di katakan bahwa pertimbangan hakim dalam memutus perkara bukan hanya berpatokan dengan undang-undang sebagai acuannya tetapi banyak sekali yang dilakukan pertimbangan-pertimbangan lainnya apabila dilihat dari aspek yuridisnya hakim akan mempertimbangkan dari keterangan-keterangan saksi, dakwaan penuntut umum, keterangan terdakwa serta barang-barang bukti pendukungnya tentunya hakim juga mempertimbangkan dari aspek Non Yuridis seperti melihat dari latar belakang terdakwa, kondisi terdakwa, sikap serta ke imanan terdakwa sebagai umat beragama, pertimbangan-pertimbangan ini dilakukan dalam memutus perkara demi terciptanya suatu keadilan bagi setiap warga negara dan melindungi hak asasi setiap warga negara republik indonesia yang sangat menjunjung tinggi hak asasi manusia.

\section{SIMPULAN DAN SARAN \\ 1. Simpulan}

Dari pembahasan diatas, dapat ditarik kesimpulan bahwa pengaturan sanksi pidana terhadap tindak pidana pembobolan rekening melalui Anjungan Tunai Mandiri (ATM) dalam Kitab Undang - Undang Hukum Pidana pencurian itu terdapat dalam Pasal 362 KUHP, dalam Undang - Undang Nomor 11 Tahun 2008 tentang Informasi dan Transaksi Elektronik (ITE) pencurian itu terdapat dalam pasal 30 ayat (1), pasal 30 ayat (3), pasal 32 ayat (2), pasal 32 ayat (3), pasal 36. Serta ada penambahan dari Undang - Undang Nomor 3 Tahun 2011 tentang Transfer Dana pencurian itu terdapat dalam pasal 81, pasal 83 ayat (1), pasal 83 ayat (2), pasal 86. Sedangkan dalam Undang-Undang Nomor 10 Tahun 1998 tentang Perbankan tidak di atur secara terperinci tentang perlindungan hukum bagi nasabah bank atau korban dari pelaku tindak pidana pembobolan rekening melalui Anjungan Tunai Mandiri (ATM).

Dalam Putusan Nomor: 688/ Pid.B/2012/ PN.Dps. hakim memutuskan perkara bahwa terdakwan Teguh T. Khasan telah terbukti secara sah dan meyakinkan bersalah melakukan tindak pidana secara melawan hukum membeli, menyewakan, menukar, menerima sebagai gadai, menerima sebagai hadiah atau dengan pengharapan akan memperoleh keuntungan menjual, menyimpan, menukarkan, menggadaikan, mengangkut, menyimpan atau menyembunyikan suatu barang yang diketahuinya atau secara patut harus diduganya bahwa benda tersebut telah diperoleh karena kejahatan dan telah menerima atau menguasai penempatan, pertransferan, pembayaran, hibah, sumbangan, penitipan, penukaran atau menggunakan harta kekayaan yang diketahui atau patut diduganya merupakan hasil tindak pidana sebagaimana dimaksud dalam pasal 2 ayat (1) dengan tujuan menyembunyikan atau menyamarkan asal usul harta kekayaan, pertimbangan hakim dalam memutus perkara tersebut bukan hanya berpatokan dengan undang-undang sebagai acuannya tetapi banyak sekali pertimbangan-pertimbangan lainnya bukan hanya melihat dari dari aspek yuridisnya tetapi juga mempertimbangkan dari aspek Non Yuridis.

\section{Saran}

Bagi Pemerintah dan pihak keamanan, saran yang dapat diberikan yaitu agar selalu mengawasi setiap atm yang ditelakan pada titik tertentu dan secara rutin menjaga agar menghindarkan dari tindak pidana pencurian yang mengakibatkan kerugian bagi negara dan masyarakat. Kegiatan pencurian dilakukan hanya pada malam hari membuat pihak terkait melakukan pengawasan ekstra.

Bagi Masyarakat selalu waspada terkait orang mencurigakan saat hendak masuk ke ATM atau setelah berada di ruang ATM, karena kita tidak tahu niat dari seseorang yang dianggap mencurigakan, melakukan penarikan atau menabung uang melalui ATM merupakan akternatif tersingkat saat ini namun kemudahan tersebut dapat memudahkan juga bagi seorang atau kelompok yang akan menjalankan aksinya. Para perampok tidak lagi perlu mencuri dari bank melainkan namun hanya melalui mesin ATM.

\section{DAFTAR PUSTAKA}

Ahmad, B. (2008). Metode Penelitian Hukum. Pustakasetia Bandung: Pustakasetia.

Amalia, R. S. (2015). Tinjauan Yuridis terhadap Tindak Pidana Pembobolan Dana Nasabah Bank Cimb Niaga Sebagai Tindak Pidana di Bidang Perbankan (Studi Kasus Putusan Pengadilan Negeri Makassar No. 403/Pid.B/2011/PN.Mks) (Universitas Hasanuddin). Retrieved from https://core.ac.uk/download/pdf/77625551.pdf

Ekawati, D. (2018). Perlindungan Hukum terhadap Nasabah Bank yang Dirugikan Akibat Kejahatan Skimming Ditinjau dari Perspektif Teknologi Informasi dan Perbankan. Unes Law Review, 1(2). Retrieved from http//garuda.ristekbrin.go.id/documents/detail/895120 
Enrick, M. (2019). Pembobolan ATM Menggunakan Teknik Skimming Kaitannya dengan Pengajuan Restitusi. Jurist-Diction Law Journal, 2(2). Retrieved from https://ejournal.unair.ac.id/JD/article/view/14252

Prasetyo, T. (2010). Hukum Pidana. Jakarta: Rajawali Pers.

Prodjodikoro, W. (2003). Tindak-tindak Pidana Tertentu di Indonesia. Bandung: PT. Refika Aditama.

Samudra, A. H. (2019). Modus Operandi dan Problematika Penanggulangan Tindak Pidana Penipuan Daring. Mimbar Hukum, 31(1). Retrieved from https:/jurnal.ugm.ac.id/jmh/article/view/34786

Siregar, R. G., \& Swardhana, I. G. M. (2016). Penerapan Sanksi terhadap Tindak Pidana Pencurian dengan Cara Pembobolan Anjungan Tunai Mandiri (Studi Kasus di Bca Denpasar). Kertha Wicara: Fakultas Hukum Universitas Udayana, 5(3). Retrieved from https://ojs.unud.ac.id/index.php/kerthawicara/article/view/20147

Sudarsono. (1992). Kamus Hukum. Jakarta: Rineka Cipta.

Utami, I. T., \& Taufiq, M. (2018). Analisis Yuridis Kasus Pembobolan Rekening pada Bank Mandiri. Jurnal Living Law, 10(1). Retrieved from https://ojs.unida.ac.id/livinglaw/article/view/1493

Utrecht, E. (1963). Pengantar HukumAdministrasi Negara Indonesia.Jakarta: Penerbit dan Balai Buku ichtiar.

Waluyo, B. (2002). Penelitian Hukum Praktek. Jakarta: Sinar Grafika.

Wardhana, G. (2011). Penanggulangan Tindak Pidana Pembobolan Anjungan Tunai Mandiri oleh Polri: Studi di Polresta Pasuruan (Universitas Brawijaya). Retrieved from http//repository.ub.ac.id/111186/ 